\title{
THE ACT OF READING THOREAU'S WALDEN
}

Ana Lúcia Almeida Salles*

ABSTRACT :

This essay investigates Henry David Thoreau's Walden from the perspective of Wolfgang Iser's theory of readerresponse. The present analysis demonstrates the presence of negations and blanks, and detects strategies that lead the reader to respond by assembling meanings, constructing images, identifying metaphors, and participating in some of the narrator's transcendental experiences.

KEY WORDS: Henry David Thoreau, Wolfgang Iser, reader-response theory, textual strategies.

Reader-Response theorists defend that reader and text are partners in a transactional experience of the production of meaning, in which the reader actively constructs the meaning or meanings of a book, while the text acts as a stimulus for the reader to react, also limiting the range of acceptable meanings so that the reader will not go too far from what is written on the page. Wolfgang Iser, in The Act of Reading: A Theory of Aesthetic Response, pays special attention to the reading process itself. Yet, the use of his theory to support a study of Henry David Thoreau's Walden does not result in establishing meanings for that narrative; by exploring the reader's reactions potentialized by the text, it rather points out textual strategies that may lead the reader to construct those meanings.

For Iser, indeterminacies, expressed by "negations" and "blanks," are fundamental conditions for the interaction between reader and text. When the validity of norms and conventions from the real world is negated in the fictional realm of a text, a blank is created in the reader's mind, and he has to fill it

|* Mestre em Letras: Estudos Literários (Ārea de concentração: Literaturas de Expressão Inglesa), 2003. 


\section{EMTESE}

Belo Horizonte, v. 8, p. I-243, dez. 2004

through ideation. In Walden, an unusual way of opening a statement with a negation so as to introduce a new idea constitutes one of its textual characteristics and a basic feature used by the narrator to criticize that which is traditionally considered a "value" of social, political, religious, or cultural order. For example, the narrator opens the text by declaring what he is not going to do: "I do not propose to write an ode to dejection," which leads the reader to expect that immediately after another idea will oppose or contrast the previous idea of dejection, which in fact happens: "but to brag as lustily as a chanticleer in the morning, standing on his roost, if only to wake my neighbors up" $(1966: 1)$. Summing up the situation, the first part of the introductory sentence rejects an idea, while the second part offers an alternative. According to Joseph Wood Krutch, Thoreau's criticism intends "to clear the way for a vision of things as they ought to be" $(1982: 3)$. Thus, the text provides conditions for the reader to consider what idea should fill the vacancy created by the negation.

The problem of describing how norms are negated and how the text potentializes the reader's attitudes can be solved through the description of what Iser calls "strategies" - narrative techniques and the structure that underlies them. In Walden seldom does the reader find ideas negated through the simplistic binary pattern of the kind "I don't do this - I do that," or "Don't do this - Do that." Most of the time the reader finds a kind of inversion, in which ideas are devaluated by means of paradoxes or unexpected "upside down," indirect ways of presentation, so that the reader cannot help but see how differently norms and convention can be considered. The narrator declares, for example, "I see young men, my townsmen, whose misfortune it is to have inherited farms ... for these are more easily acquired than got rid of" (2, emphasis mine). The paradoxical image leads the reader to, at least, establish a contrast between the concepts that have so far guided his perspectives about the matter and the unusual perspective proposed by the text. The reader is also told that sometimes when the farmer has got his house, he may be poorer, because it is actually the house that has got him; he will read that "men are not so much the keepers of herds as herds are the keepers of men" (38); and that man "considers, not what is truly respectable, but what is respected" (14). In "[m] any are concerned about the monuments of the West and the East, - to know who 
built them. For my part, I should like to know who in those days did not build them, - who were above such trifling" (39), a traditional attitude is simply turned upside down, and it is to this new image suggested by the text that the reader's mind will have to accommodate and respond in some way. The inversion disqualifies (or negates) what was traditionally seen as true, providing a gap for an ideal condition to be imagined.

The narrator at times conveys an idea or a concept not through what is affirmed, but through what is negated in a passage. To talk about transcendental moments of meditation, the narrator reports that he sat in solitude, without acknowledging the passing time, something considered a waste of time by his neighbors. "They [hours] were not time subtracted from my life, but so much over and above my usual allowance" (75), he indicates; and his apparent indolence, he decides, is the best way to earn a living. Thus, time loses here its traditional position: using time for "doing" something is negated, while using time for "not doing" something is valued. Transcendence is treated as a passive act. When the narrator realizes that he "grew in those seasons like corn in the night" (75), he is precisely indicating that spiritual improvement is immeasurable while it is in progress, though its result is indeed palpable.

Iser points out the importance of strategies, "which lay down the lines along which the text is to be actualized" (1981:85). A basic strategy in Walden, expressed by a peculiar way of presenting ideas in a kind of "dual pattern," lays down the lines for the reader to perceive a permanent perspective of duality in the narrative from its beginning: most of the narrative's elements (ideas, sentence structure, subject matters, etc.) can be divided, for the sake of scrutiny, into two parts, each one proposing a different focus of attention. For example, the narrator's very first declaration about playing the role of a chanticleer splits into two aspects - what he is not going to do (an ode to dejection) versus what he is going to do in the narrative (brag to wake his neighbors up); the discussion about hunting pairs with the spiritual decisions of John Farmer; a destructive battle between two groups of ants contrasts with a "dialogue" between a goose and a cat-owl; the attribution of high spirituality to some animals opposes the term "brute" attributed to them; titles of chapters also form contrastive pairs sometimes (for instance, 


\section{EMTESE}

Belo Horizonte, v. 8, p. I-243, dez. 2004

"Reading" and "Sounds;" "Solitude" and "Visitors"); and so on. The dual pattern requires constant adjustments in the reader's mind, which has to oscillate between ideas of generally opposite nature. So, the strategy predisposes the reader to the oscillation between literal and metaphorical meanings (usually of material and spiritual nature) in the narrative.

As Joseph R. McElrath comments, the narrator "moves through the objective, external world, but the real focus of the book is on the internal, subjective world of the narrator's self, or soul, as it moves toward spiritual fulfillment and ecstasy." He proceeds, "This movement toward spiritual perfection, the main movement of Walden, is expressed through metaphors" (1995:25). The cabin as the narrator's inner being is a metaphor that is gradually developed as the narrator, by telling his reader how he chose the place in which to settle, provides information in terms of facts of imagination - his imaginary business with all the owners of farms near his place - this way negating the importance attributed to ownership of real houses, and inverting social values: "for a man is rich in proportion to the number of things which he can afford to let alone" (55). The establishment of Walden Pond as the narrator's higher self is stimulated by the use of metaphorical language, by a strategic description of its attributes, and by the narrator's guidance for the construction of images relating the pond to states of transcendental experiences. The pond's water, "full of light and reflections, becomes a lower heaven itself" (58); and the pond's description is nothing less than one of perfection - its fish are "cleaner, handsomer, and firmer fleshed" than any other (124); it is "remarkable for its depth and purity" (118). Not merely another element of nature, but rather portrayed as something ethereal, the pond is "this element which was scarcely more dense" than the air (117), exhaustively associated to the idea of illumination through images that refer to a "glassy surface," "gleaming," "reflections," "brightness," "sun," "bright flash" (125), "shine," "light," "precious stones," "1ight dust-cloth" (126), "flakes of light" (126-27).

Iser argues that it is "a sequence of images that eventually results in his [the reader's] constituting the meaning of the text" (141). The two issues, construction of meaning and formation of images, have distinct definitions, but they are many times combined during the act of reading, when it is impossible to 
draw a line between what is the meaning of a passage and the image produced in the reader's mind. And because different kinds of images inspired by different texts yield different results, it is possible, in the case of Walden, to establish that transcendental experiences for the reader are potentialized by the text, insofar as it guides the reader to images that represent altered states of consciousness. These are extra-ordinary situations that transcend the habitual states in which consciousness focuses on customary patterns of sensations, emotions, perceptions, thought, etc. The passage in which Walden's narrator, while fishing, wanders "to vast and cosmogonal themes in other spheres," exemplifies an altered state of consciousness. It is a "faint jerk" that interrupts what he calls his "dreams" and brings him back to nature and to his customary level of consciousness (117). Absorbed in these kinds of images, the reader may experience what Iser describes as an irrealization, "in the sense that we are preoccupied with something that takes us out of our own given reality" (140).

At times the text may invite the reader to visualize a scene from the narrator's perspective, thus contributing for the narrator and the reader to share experiences. For example:

Paddling gently ... I was surprised to find myself surrounded by myriads of small perch ... constantly rising to the surface and dimpling it ... In such transparent and seemingly bottomless water, reflecting the clouds, I seemed to be floating through the air as in a balloon, and their swimming impressed me as a kind of flight or hovering, as if they were a compact flock of birds passing just beneath my level on the right or left ... (127)

The "transparence" and the apparent "bottomless" quality of the water can only be seen from above - the very position of the narrator in relation to the lake. The unusual combination of these two kinds of sights - to look through and to look at a point in the infinitude - stimulates a recollection of special ways of looking at things, as when one stands still, with a fixed, but vague sight, the scenery around being automatically perceived, when one actually looks through the external objects, because his attention is turned to an inside world of thoughts; or the special way of looking that causes a 3D-image to sprout from the scribbles of a stereograph. The choice of words also influences the kind of image that the reader is to form. "Transparence" is placed in-between the definitions of existent 


\section{EMTESE}

Belo Horizonte, v. 8, p. I-243, dez. 2004

and non-existent. We cannot see it; we see what is beyond it, or we see something because transparence is between that something and us. It is there, but is not itself a barrier, but rather the concealment of a barrier. It does not tell about a presence, but rather the absence of something. "Bottomless" is also an artfully chosen term that brings about the notion of infinitude, a concept that can only be absorbed through an expansion of the mind. Instructed to follow the clouds' gentle movement repeated in the water, the reader can recognize inside himself the narrator's sensation of "floating through the air." From a passage that reunites effects of third-dimension and levitation; and image effects that require participation of reality and imagination (perch that become birds, clouds that are but a reflection), one can gauge the dimension of involvement on the part of the narrator in the experience, and, consequently, the reader's possibilities of involvement as well.

The possibility of any experience is latent in the reader, who can, through reading, "bring to light a layer of his personality that he had previously been unable to formulate in his conscious mind" (50), as Iser affirms. The image that the narrator forms is neither the one he would have before, without the narrator's lenses, or that of the narrator. Its production implies in consequences. "The image and the reading subject," Iser says, "are indivisible. ... it means in effect that the reader is absorbed into what he himself has been made to produce through the image; he cannot help being affected by his own production . . ." (140). If the image comes from references to an altered state of consciousness of the narrator, it is likely that this image propitiates an experience of similar nature in the reader.

In addition to those blanks created by negations, a reticent narrative also stimulates a great deal of ideation on the part of the reader of Walden. In "The Village" the narrator tells about his crossing the woods, but the reader is never told about what really happened there, for, instead of facts, only results are reported: to be lost in the woods is as "surprising and memorable, as well as valuable experience" (114), and "[n] tot till we are lost . . . do we begin to find ourselves" (115). But perhaps the most significant gap comes at the end of the narrative. Having extensively established the importance that a close contact with nature had for his evolution, the narrator justifies his departure from walden with 
the laconic, "I left the woods for as good a reason as I went there. Perhaps it seemed to me that I had several more lives to live, and could not spare any more time for that one" (213). This is an explanation, but certainly a vague one, which the reader will have to complete by himself. By discontinuing an experience that had been presented as rather effective and successful, the narrator, in a certain sense, is negating it, and compelling the reader to consider it from perspectives that will reveal its relative value: it is not the only way, something else can be explored by the reader. The narrative becomes a partial facet of a meaning whose totality only the reader can construct for himself. Iser hints at a step further: "The constitution of meaning ... gains its full significance when something happens to the reader" (152). What happens to the reader when he "grasps" the meaning of Walden only the reader knows. However, the reader will never be the same after actualizing the meanings and images potentialized in Thoreau's work.

NOTES

1. All quotes from Walden are taken from the 1966 edition, and those from The Act of Reading: A Theory of Aesthetic Response are from the 1981 edition. So as not to be repetitive, I have included the date of publication only in the first time I quote these works.

2. For the sake of economy, "the reader", male or female, is referred to by the pronoun "he."

RESUMO:

A investigação de Walden, de Henry David Thoreau, baseada na teoria da estética da recepção de Wolfgang Iser demonstra a presença da "negação", do "lugar vazio" e de estratégias textuais que levam o leitor à constituição do sentido do texto, às imagens, às metāforas e à participação em experiências transcendentais do narrador.

PALAVRAS-CHAVE: Henry David Thoreau, Wolfgang Iser, estética da recepção, estratégias textuais. 


\section{EMTESE}

Belo Horizonte, v. 8, p. I-243, dez. 2004

\section{REFERÊNCES}

ISER, Wolfgang. The Act of Reading: A Theory of Aesthetic Response. Baltimore: Johns Hopkins UP, 1981.

KRUTCH, Joseph Wood (Ed.). Introduction. Walden and Other Writings by Henry David Thoreau. By Henry David Thoreau. Toronto: Bantam, 1982. 1-23.

MCELRATH, Joseph R., Jr. Thoreau's Walden. Cliffs Notes. Ed. Gary Carey. Lincoln, NE: Cliffs Notes, 1995.

THOREAU, Henry David. Walden and Civil Disobedience. Norton Critical Editions. Ed. Owen Thomas. New York: Norton, 1966. 